\title{
Testicular Cancer pN1 TNM Finding v8
}

National Cancer Institute

\section{Source}

National Cancer Institute. Testicular Cancer pN1 TNM Finding v8. NCI Thesaurus. Code C140222.

Testicular cancer with metastasis with a lymph node mass $2 \mathrm{~cm}$ or smaller in greatest dimension and less than or equal to five nodes positive, none larger than $2 \mathrm{~cm}$ in greatest dimension. (from AJCC 8th Ed.) 